\title{
Potensi, Peluang Dan Kendala Pengembangan Kakao Di Provinsi Jambi: Sebuah Kajian Pustaka
}

\author{
Suharyon, Busra \\ Balai Pengkajian Teknologi Pertanian (BPTP) Jambi, Indonesia
}

\begin{abstract}
ABSTRAK
Pada era globalisasi ini pelaksanaan pembangunan perkebnan harus memperhatikan kelestarian ekosistem dan memberdayakan masyarakat sekitar sehingga tidak akan mengakibatkan terjadinya degradasi lahan maupun permasalahan sosial yang lain. Karena pada dasarnya program pembangunan pertanian berkelanjutan (berwasan lingkungan) berawal dari permasalahan pokok tentang bagaimana mengelola sumberdaya lahan secara bijaksana sehingga bisa menopang kehidupan yang berkelanjutan bagi masyarakat dan generasi penerus. Kelembagaan petani perlu dikuatkan melalui pelatihan dan pendampingan petani serta memperbanyak petugas pendamping di lapangan. Kemitraan usaha antara industri/eksportir dengan petani/kelompok tani perlu ditumbuhkan dan ditingkatkan. Kemitraan usaha yang diharapkan adalah kemitraan yang profesional saling menguntungkan dan tidak terbatas dan hanya pemasaran hasil tetapi termasuk teknis budidaya dan peningkatan mutu. Meningkatkan kualitas ekspor kakao dari kakao biji menjadi kakao bubuk atau produk olahan.
\end{abstract}

Kata Kunci: Kakao, Jambi, Kajian Pustaka

\section{PENDAHULUAN}

\subsection{Latar Belakang}

Provinsi Jambi merupakan salah satu daerah penghasil tanaman kakao. Luas areal perkebunan kakao di Provinsi Jambi dari tahun 2011 sampai tahun 2015 terus mengalami peningkatan. Tercatat pada tahun 2011 luas areal perkebunan kakao adalah 1.986 Ha dan sampai ditahun 2015 telah mencapai 2.270 Ha. Peningkatan jumlah areal tanaman kakao tidak lain dikarenakan semakin tingginya minat petani terhadap budidaya kakao. Budidaya kakao dirasa memberikan keuntungan untuk rumah tangga petani sehingga pemanfaatan lahan kosong ditingkatkan dengan melaksanakan budidaya kakao.

Pada tahun 2011 produksi tanaman kakao di Provinsi Jambi mencapai 663 ton. Produksi kakao mengalami fluktuasi yang tidak terlalu signifikan dimana pada tahun 2015 mampu meningkat menjadi 718 ton yang sebelumnya hanya 645 ton. Produktivitas kakao mengalami penurunan dari tahun 2011 sampai tahun 2014 dan kembali meningkat pada tahun 2015 sebesar 0,614 ton/ha (Tabel 1).

Tabel 1. Luas Lahan Produksi dan Produktivitas Kakao Jambi 2015

\begin{tabular}{|c|c|c|c|c|c|c|c|}
\hline \multirow{2}{*}{ No } & \multirow{2}{*}{ Kabupaten } & \multicolumn{4}{|c|}{ Luas Area (Ha) } & \multirow{2}{*}{$\begin{array}{l}\text { Produksi } \\
\text { (Ton) }\end{array}$} & \multirow{2}{*}{$\begin{array}{l}\text { Produktivitas } \\
\text { (Ton/Ha) }\end{array}$} \\
\hline & & TBM & $\mathbf{T M}$ & TTM/TR & Total & & \\
\hline 1 & Batanghari & 3 & 46 & 9 & 58 & 45 & 0,978 \\
\hline 2 & Muaro Jambi & 280 & 388 & 116 & 784 & 286 & 0,737 \\
\hline 3 & Bungo & 13 & 26 & 2 & 41 & 30 & 1,154 \\
\hline 4 & Tebo & 110 & 46 & 3 & 159 & 24 & 0,522 \\
\hline 5 & Merangin & 81 & 85 & 7 & 173 & 55 & 0,647 \\
\hline 6 & Tanjab Barat & 121 & 253 & 4 & 378 & 84 & 0,332 \\
\hline 7 & Tanjab Timur & 61 & 221 & 87 & 369 & 167 & 0,756 \\
\hline 8 & Kerinci & 162 & 50 & 8 & 220 & 24 & 0,480 \\
\hline 9 & Sungai Penuh & 33 & 55 & - & 88 & 27 & 0,491 \\
\hline & Jumlah & 864 & 1.170 & 236 & 2.270 & 742 & 6,09 \\
\hline
\end{tabular}


Perkebunan kakao di Provinsi Jambi tersebar di beberapa kabupaten yang ada di Provinsi Jambi. Menurut data Dinas Perkebunan Provinsi Jambi tahun 2015, Kabupaten Muaro Jambi memiliki luas panen tertinggi sebesar $388 \mathrm{Ha}$ dan produksi tertinggi sebesar 286 ton, namun produktivitas tanaman kakao di Kabupaten Muaro Jambi masih rendah dibandingkan dengan beberapa kabupaten di Provinsi Jambi yang juga mengusahakan kakao. Dilihat dari produktivitas tanaman kakao, Kabupaten Muaro Jambi berada pada urutan ke 4 dibawah Kabupaten Bungo, Batanghari dan Tanjung Jabung Timur yaitu sebesar 0,737 ton/ha.

Luas panen perkebunan kakao di Kabupaten Muaro Jambi terus mengalami peningkatan dalam 5 tahun terakhir. Luas panen tertinggi di Kabupaten Muaro Jambi terjadi pada tahun 2015, namun produksi kakao mengalami fluktuasi yang tidak terlalu signifikan dan produktivitas kakao yang cenderung mengalami penurunan. Pada tahun 2011 produktivitas kakao di Kabupaten Muaro Jambi mencapai 0,932 ton/ha, tetapi pada tahun 2015 hanya mencapai 0,737 ton/ha. Jumlah petani yang mengusahakan tanaman kakao terus mengalami peningkatan dari tahun 2011 sampai tahun 2015. Pada tahun 2011 berjumlah 577 KK melambung tinggi pada tahun 2015 menjadi 1077. Hal ini menunjukkan bahwa minat petani yang tinggi untuk berbudidaya tanaman kakao yang diimbangi dengan peningkatan luas panen kakao. Perkebunan kakao di Kabupaten Muaro Jambi tersebar hampir diseluruh kecamatan. Hanya satu kecamatan yang tidak mengusahakan tanaman kakao yaitu Kecamatan Sungai Bahar.

`Tabel 2. Luas Lahan, Produksi, dan Produktivitas Kakao di Muaro Jambi Tahun 2015

\begin{tabular}{|c|c|c|c|c|c|c|c|}
\hline \multirow{2}{*}{ No } & \multirow[b]{2}{*}{ Kecamatan } & \multicolumn{4}{|c|}{ Luas Areal (Ha) } & \multirow{2}{*}{$\begin{array}{l}\text { Produksi } \\
\text { (Ton) }\end{array}$} & \multirow{2}{*}{$\begin{array}{l}\text { Produktivitas } \\
\text { (Ton/Ha) }\end{array}$} \\
\hline & & TBM & TM & TTM/TR & Total & & \\
\hline 1 & Jaluko & 20 & 7 & - & 27 & 5 & 0,714 \\
\hline 2 & Sekernan & 62 & 8 & - & 70 & 5 & 0,625 \\
\hline 3 & Kumpeh & 97 & 302 & 104 & 503 & 223 & 0,738 \\
\hline 4 & Muaro Sebo & 46 & 18 & 3 & 67 & 12 & 0,667 \\
\hline 5 & Mestong & 9 & 2 & - & 11 & 1 & 0,500 \\
\hline 6 & Kumpeh Ulu & 19 & 22 & 9 & 50 & 15 & 0,682 \\
\hline 7 & Sungai Bahar & - & - & - & - & - & - \\
\hline \multirow[t]{2}{*}{8} & Sungai Gelam & 27 & 29 & - & 56 & 25 & 0,862 \\
\hline & Jumlah & 280 & 388 & 116 & 784 & 286 & 4,788 \\
\hline
\end{tabular}

Sumber : Dinas Kehutanan dan Perkebunan Kabupaten Muaro Jambi, 2015

Dari Tabel 2 dapat dijelaskan bahwa di Kabupaten Muaro Jambi yang memiliki sentra perkebunan kakao adalah Kecamatan Kumpeh. Kecamatan Kumpeh memiliki luas panen dan produksi kakao tertinggi dibandingkan 6 kecamatan lainnya. Kecamatan Kumpeh mampu menyumbang $78 \%$ dari total luas panen dan produksi kakao secara keseluruhan di Kabupaten Muaro Jambi yang diusahakan pada tahun 2015. Meskipun luas panen dan produksi kakao di Kecamatan Kumpeh paling tinggi di Kabupaten Muaro Jambi, produktivitas kakao di Kecamatan Kumpeh masih berada di bawah Kecamatan Sungai Gelam. Pemanfaatan luas lahan yang kurang baik menjadi salah satu penyebab rendahnya produktivitas kakao di Kecamatan Kumpeh. 
Tabel 3. Luas Lahan, Produksi, dan Produktivitas Kakao di Kumpeh 2011 - 2015

\begin{tabular}{ccccccc}
\hline & & \multicolumn{3}{c}{ Luas Areal (Ha) } & Produksi & $\begin{array}{c}\text { Produktivitas } \\
\text { Tahun }\end{array}$ \\
\cline { 3 - 5 } TBM & TM & TTM/TR & Jumlah & (Ton) & (Tona) \\
\hline 2011 & 105 & 273 & 93 & 471 & 259 & 0,969 \\
2012 & 94 & 292 & 94 & 480 & 218 & 0,747 \\
2013 & 74 & 302 & 104 & 480 & 223 & 0,738 \\
2014 & 89 & 302 & 104 & 495 & 223 & 0,738 \\
2015 & 97 & 302 & 104 & 503 & 223 & 0,738 \\
\hline \hline
\end{tabular}

Sumber : Dinas Kehutanan dan Perkebunan Kabupaten Muaro Jambi, 2015

Luas panen kakao di Kecamatan Kumpeh mengalami kenaikan dari tahun 2011-2015 (Tabel 3). Namun, peningkatan luas panen tersebut tidak sejalan dengan produksi dan produktivitas kakao. Produksi kakao mengalami fluktuasi yang masih berada pada garis yang tidak jauh perbedaannya. Sedangkan produktivitas kakao yang menjadi permasalahan, karena turun begitu drastis dari tahun 2011 sampai tahun 2015. Pada tahun 2011 masih menunjukkan angka 0,969 ton/ha, akan tetapi jauh turun menjadi 0,738 ton/ha pada tahun 2015 . Kecamatan Kumpeh yang memiliki luas panen dan produksi komoditi kakao yang cukup baik, masih memerlukan penanganan yang serius sehingga dapat meningkatkan produksi yang ada.

Sebagian besar penduduk bermata pencarian pokok sebagai petani, khususnya petani kakao dan menggantungkan hidupnya dari usahatani yang dijalankannya. Penghasilan dari usahatani kakao dapat dikatakan mampu menopang hidup keseharian petani kakao. Produktivitas kakao di Kecamatan Kumpeh mengalami penurunan dari tahun 2011 sampai tahun 2015 secara teknis dapat disebabkan oleh beberapa hal diantaranya adalah petani mengabaikan cara budidaya tanaman kakao yang baik, serangan hama dan penyakit, belum banyak petani yang melakukan perawatan kebun secara baik karena kurangnya pengetahuan dan kesadaran dari mereka, pola tanam yang kurang baik, minimnya pendampingan kepada petani oleh petugas PPL, keterbatasan modal produksi dan belum optimalnya penggunaan faktor produksi. Penggunaan faktor produksi yang dimaksud adalah luas lahan, tenaga kerja, dan modal. Modal dapat berupa pupuk dan obatobatan.

Jenis kakao yang diusahakan di Kecamatan Kumpeh adalah jenis forastero. Jarak tanam yang diterapkan di Kecamatan Kumpeh masih dapat dikatakan belum teratur dan pola tanam yang diterapkan adalah tumpang sari, akan tetapi tidak semua lorong pada jarak tanam kakao ditanami tanaman tumpang sari. Pada saat ini umur tanaman kakao di Kecamatan Kumpeh berkisar dari umur 7 tahun sampai umur 16 tahun dan rata-rata jumlah pohon per hektar adalah 630 batang (Oktavia, 2016). Menurut Siregar (1989) tanaman kakao mulai memproduksi buah pada tahun ke-3 dan produksi maksimal dicapai pada tahun ke-9 sampai dengan tahun ke-14. Pada saat umur 9 sampai 14 tahun tanaman kakao mampu memproduksi hingga 1 ton biji kering per ha dalam satu tahun dan merupakan umur baik untuk mengasilkan output yang maksimum. Disimpulkan bahwa pada saat ini umur tanaman kakao di Kecamatan Kumpeh sedang berada pada umur produksi maksimal.

Tenaga kerja masih mengabaikan cara budidaya dan perawatan kakao yang baik. Penggunaan luas lahan yang belum optimal karena penerapan pola tanam yang kurang baik. Penggunaan pupuk yang tidak sesuai ketepatan menyebabkan kakao tidak menghasilkan produksi yang maksimal. Pupuk diberikan tidak tepat dosis dan tidak tepat waktu. Penggunaan obat-obatan yang tidak sesuai ketepatan juga menyebabkan tanaman kakao terserang hama dan penyakit. Keterbatasan modal petani dan harga input produksi yang tinggi menjadi penyebab pemberian pupuk dan obat-obatan belum efisien. Penggunaan faktor produksi usahatani kakao akan berpengaruh terhadap besar kecilnya hasil produksi. 
Harga pupuk dan obat-obatan hampir terus mengalami kenaikan. Pada tahun 2015 harga pupuk Urea mencapai Rp 2.500/kg, pupuk TSP Rp 2.700/kg dan pupuk KCl Rp 3.000/kg. Harga pupuk Urea dan $\mathrm{KCl}$ mengalami peningkatan dari tahun 2011 sampai tahun 2015, sedangkan pupuk TSP mengalami fluktuasi yang cenderung meningkat dari tahun 2011 sampai tahun 2015. Harga obat-obatan seperti Matador, Sidametrin, dan Gramokson terus mengalami peningkatan selama 5 tahun terakhir. Harga Matador mencapai Rp 225.000/ltr pada tahun 2015, yang pada tahun 2011 hanya sebesar Rp 180.000/ltr. Harga Sidametrin melambung jauh dari Rp 18.000/ltr pada tahun 2011 menjadi Rp 35.000/ltr pada tahun 2015. Sedangkan harga Gramokson naik Rp 5000 setiap tahunnya, dari harga Rp 40.000/ltr pada tahun 2011 menjadi Rp 60.000/1tr pada tahun 2015 (lampiran 3). Harga pupuk dan obat-obatan yang tinggi dapat menyebabkan petani

berpikir untuk mengurangi dosis penggunaan pupuk dan obat-obatan. Hal yang seperti itu dapat menyebabkan produksi kakao yang dihasilkan semakin menurun. Biaya pupuk dan pestisida yang tinggi dapat menurunkan tingkat keuntungan usahatani kakao.

Di Kabupaten Muaro Jambi harga kakao mengalami fluktuasi dalam 5 tahun terakhir. Pada tahun 2011 mencapai Rp 17.000/kg, tahun 2012 dan 2013 mengalami penurunan yaitu Rp $16.000 / \mathrm{kg}$ dan $\mathrm{Rp} 14.400 / \mathrm{kg}$ sedangkan tahun 2014 dan 2015 naik menjadi Rp 22.100/kg. Perbandingan antara harga input dan harga output adalah upaya untuk mencapai indikator efisiensi. Keterbatasan faktor-faktor biaya produksi sebagai alokasi input seperti upah tenaga kerja, biaya pupuk, biaya pestisida dan sewa lahan serta faktor lainnya seperti cara budidaya dan penggunaan faktor produksi akan berpengaruh terhadap produksi dan pendapatan dalam usahatani kakao secara optimal sehingga dari keadaan ini petani dihadapkan pada pilihan penggunaan sumberdaya usahatani dan dituntut menerapkan upaya-upaya efisiensi sumberdaya yang terbatas sehingga menguntungkan dalam usahatani kakao.

Menurut Suratiyah (2011) ilmu usahatani adalah ilmu yang mempelajari cara-cara petani menentukan, mengorganisasikan, dan mengkoordinasikan penggunaan faktor-faktor produksi seefektif dan seefisien mungkin sehingga usaha tersebut memberikan pendapatan semaksimal mungkin. Dikaitkan dengan teori tersebut penggunaan faktor produksi yang efektif dan efisien dapat memberikan pendapatan yang maksimal bagi petani. Jika faktor produksi yang efisien mampu memberikan produksi yang tinggi maka penerimaan usahatani yang diperoleh petani akan meningkat dan sebaliknya jika produksi yang dihasilkan rendah maka penerimaan usahatani yang akan diperoleh petani akan sedikit pula. Harga yang diterima petani sangat menentukan berapa besar penerimaan dan keuntungan yang akan diperoleh petani. Dengan adanya peningkatan harga, maka penerimaan bersih yang akan diperoleh petani secara tidak langsung akan meningkat dan sebaliknya jika terjadi penurunan harga, maka penerimaan bersih yang akan diterima petani otomatis akan menurun juga. Penerimaan yang tinggi maka akan berdampak pada keuntungan yang tinggi.

\subsection{Kendala Pengembangan Kakao}

Sebagian besar penduduk bermata pencarian pokok sebagai petani, khususnya petani kakao dan menggantungkan hidupnya dari usahatani yang dijalankannya. Penghasilan dari usahatani kakao dapat dikatakan mampu menopang hidup keseharian petani kakao. Produktivitas kakao di Kecamatan Kumpeh mengalami penurunan dari tahun 2011 sampai tahun 2015 secara teknis ditemukan kendala pengembangan kakao diantaranya adalah petani mengabaikan cara budidaya tanaman kakao yang baik, serangan hama dan penyakit, belum banyak petani yang melakukan perawatan kebun secara baik karena kurangnya pengetahuan dan kesadaran dari mereka, pola tanam yang kurang baik, minimnya pendampingan kepada petani oleh petugas PPL, keterbatasan modal produksi dan belum optimalnya penggunaan faktor produksi. Penggunaan faktor produksi yang dimaksud adalah luas lahan, tenaga kerja, dan modal. Modal dapat berupa pupuk dan obatobatan. 
Tenaga kerja masih merupakan kendala yang masih mengabaikan cara budidaya dan perawatan kakao yang baik. Penggunaan luas lahan yang belum optimal karena penerapan pola tanam yang kurang baik. Penggunaan pupuk yang tidak sesuai ketepatan menyebabkan kakao tidak menghasilkan produksi yang maksimal. Pupuk diberikan tidak tepat dosis dan tidak tepat waktu. Penggunaan obat-obatan yang tidak sesuai ketepatan juga menyebabkan tanaman kakao terserang hama dan penyakit. Keterbatasan modal petani dan harga input produksi yang tinggi menjadi penyebab pemberian pupuk dan obat-obatan belum efisien. Penggunaan faktor produksi usahatani kakao akan berpengaruh terhadap besar kecilnya hasil produksi.

Harga pupuk dan obat-obatan hampir terus mengalami kenaikan. Pada tahun 2015 harga pupuk Urea mencapai Rp 2.500/kg, pupuk TSP Rp 2.700/kg dan pupuk KCl Rp 3.000/kg. Harga pupuk Urea dan $\mathrm{KCl}$ mengalami peningkatan dari tahun 2011 sampai tahun 2015, sedangkan pupuk TSP mengalami fluktuasi yang cenderung meningkat dari tahun 2011 sampai tahun 2015. Harga obat-obatan seperti Matador, Sidametrin, dan Gramokson terus mengalami peningkatan selama 5 tahun terakhir. Harga Matador mencapai Rp 225.000/ltr pada tahun 2015, yang pada tahun 2011 hanya sebesar Rp 180.000/ltr. Harga Sidametrin melambung jauh dari Rp 18.000/ltr pada tahun 2011 menjadi Rp 35.000/ltr pada tahun 2015. Sedangkan harga Gramokson naik Rp 5000 setiap tahunnya, dari harga Rp 40.000/ltr pada tahun 2011 menjadi Rp 60.000/Itr pada tahun 2015. Harga pupuk dan obat-obatan yang tinggi dapat menyebabkan petani berpikir untuk mengurangi dosis penggunaan pupuk dan obat-obatan. Hal yang seperti itu dapat menyebabkan produksi kakao yang dihasilkan semakin menurun. Biaya pupuk dan pestisida yang tinggi dapat menurunkan tingkat keuntungan usahatani kakao.

Di Kabupaten Muaro Jambi harga kakao mengalami fluktuasi dalam 5 tahun terakhir. Pada tahun 2011 mencapai Rp 17.000/kg, tahun 2012 dan 2013 mengalami penurunan yaitu Rp 16.000/kg dan Rp 14.400/kg sedangkan tahun 2014 dan 2015 naik menjadi Rp 22.100/kg (lampiran 4). Perbandingan (nisbah) antara harga input dan harga output adalah upaya untuk mencapai indikator efisiensi. Keterbatasan faktor-faktor biaya produksi sebagai alokasi input seperti upah tenaga kerja, biaya pupuk, biaya pestisida dan sewa lahan serta faktor lainnya seperti cara budidaya dan penggunaan faktor produksi akan berpengaruh terhadap produksi dan pendapatan dalam usahatani kakao secara optimal sehingga dari keadaan ini petani dihadapkan pada pilihan penggunaan sumberdaya usahatani dan dituntut menerapkan upaya-upaya efisiensi sumberdaya yang terbatas sehingga menguntungkan dalam usahatani kakao.

Menurut Suratiyah (2011) ilmu usahatani adalah ilmu yang mempelajari cara-cara petani menentukan, mengorganisasikan, dan mengkoordinasikan penggunaan faktor-faktor produksi seefektif dan seefisien mungkin sehingga usaha tersebut memberikan pendapatan semaksimal mungkin. Dikaitkan dengan teori tersebut penggunaan faktor produksi yang efektif dan efisien dapat memberikan pendapatan yang maksimal bagi petani. Jika faktor produksi yang efisien mampu memberikan produksi yang tinggi maka penerimaan usahatani yang diperoleh petani akan meningkat dan sebaliknya jika produksi yang dihasilkan rendah maka penerimaan usahatani yang akan diperoleh petani akan sedikit pula. Harga yang diterima petani sangat menentukan berapa besar penerimaan dan keuntungan yang akan diperoleh petani. Dengan adanya peningkatan harga, maka penerimaan bersih yang akan diperoleh petani secara tidak langsung akan meningkat dan sebaliknya jika terjadi penurunan harga, maka penerimaan bersih yang akan diterima petani otomatis akan menurun juga. Penerimaan yang tinggi maka akan berdampak pada keuntungan yang tinggi.

Menurut Hanafie (2010), petani selalu akan mencari cara mengalokasikan input seefisien mungkin untuk dapat memperoleh produksi yang maksimal karena petani berpikiran bagaimana mendapatkan keuntungan yang maksimum (profit maximization). Di lain pihak, ketika petani dihadapkan pada keterbatasan biaya dalam melaksanakan usahataninya untuk mengalokasikan input produksi, upaya memaksimalkan keuntungan tetap akan dilakukan dengan penggunaan faktor produksi seoptimal mungkin. 


\subsection{Potensi,Tantangan Pengembangan Kakao}

Selama ini Kecamatan Kumpeh Provinsi Jambi hanya terkenal dengan produksi duku. Padahal sebenarnya kakao memiliki potensi, peluang yang baik untuk dikembangkan. Kecamatan Kumpeh adalah kecamatan sebagai pemberi kontribusi terbesar penghasil kakao di Kabupaten Muaro Jambi dengan luas panen kakao yang terus meningkat pada 5 tahun terakhir. Kecamatan Kumpeh sebagai sentra produksi kakao terbesar di Kabupaten Muaro Jambi, seharusnya dapat menjaga produksinya untuk tetap terus meningkat. Namun yang terjadi produktivitas kakao menurun setiap tahunnya. Rendahnya produktivitas ini dapat disebabkan karena pengelolaan faktor produksi yang belum optimal dan kurangnya modal petani yang diakibatkan karena harga input produksi seperti pupuk dan obat-obatan yang meningkat tajam.

Petani belum mampu menerapkan teknik budidaya yang baik pada tanaman kakao padahal rata-rata harga kering di pasar domestik pada tahun 2015 mencapai Rp 22.100 per kg. Harga ini naik dibandingkan tahun 2011 sampai tahun 2013 yang hanya berkisar di bawah Rp 20.000 per $\mathrm{kg}$. Seharusnya dengan harga yang semakin membaik memberi motivasi kepada petani kakao untuk dapat menggunakan faktor produksi yang optimal sehingga produksi yang dihasilkan dapat meningkat. Hal yang harus diperhatikan adalah pertama, tingkat transformasi antara input dan output dalam fungsi produksi, kedua, perbandingan antara harga input dan harga output, kedua hal ini merupakan upaya untuk mencapai indikator efisiensi.

Penggunaan faktor produksi yang optimal akan memberikan keuntungan kepada petani. Akan tetapi, petani dihadapkan pada kondisi produktivitas menurun, harga faktor produksi cenderung naik serta harga kakao yang berfluktuasi. Produktivitas, harga faktor produksi, produksi kakao dan harga kakao akan mempengaruhi pendapatan yang akan diterima oleh petani. Penggunaan faktor produksi yang efisien akan menghasilkan produksi yang optimal. Semakin besar produksi yang dihasilkan maka semakin besar pula keuntungan yang akan diterima oleh petani. Sehingga faktor produksi merupakan faktor yang harus diperhatikan penggunaannya.

Menurut Ditjen Perkebunan, 2012, bahawa pengembangan perkebunan merupakan salah satu program pembanguan di sector pertanian yang berperan cukup besar dalam rangka perbaikan ekonomi wilayah termasuk ekonomi masyarakat yakni peningkatan pendapatan dan pemerataan usaha yang dapat menunjang peningkatan kesejahteraan rakyat. Pembangunan perkebunan kakao agar dapat berkembang secara baik berkelanjutan dan berkesinambunagn sangat berkaitan dengan segala aspek pendukung seperyti potensi sumberdaya lahan dan ketersediaan tenaga kerja yang ada diwilayah bersangkutan. Komoditas kakao merupakan salah satu komoditas perkebunan yang prospektif serta berpeluang besar dalam meningkatkan kesejahteraan masyarakat karena sebagian besar diusahakan melalui perkebunan rakyat (94\%). Komoditas kakao penghasil devisa Negara, sumbsrr pendapatan petani lapangan kerja petani, mendorong pengembangan agribisnis dan agroindustri, pengembangan wilayah serta pelestarian lingkungan.

Sebagai tindak lanjut perlunya meningkatkan kelas kakao karena saaat ini masih ada yang menjual kakao dengan kualitas kurang baik. Untuk upaya kebijakan antar sesame produsen dari hulu hilirnya dilakukan dalam rangka menambah daya saing kakao. Karena sudah saatnya kakao, dibenahi mutu dan kualitasnya sesuai dengan tuntutan pasar kakao baik pada mutu dan kualitas serta ditingkatkan infrastruktur benih dan keamanan produk. Pemerintah terus berupaya mengangkat mutu kakao melalui berbagai program peningkatan mutu dan produktivitas biji kakao antara lain melalui program program Gernas Kakao (Gerakan Nasional Penimgkatan Produksi dan Mutu Biji Kakao, yang dilanjutkan dengan penyusunan Standar Kakao Berkelanjutan serta melalui berbagai kebijakan antara lain dikeluarkannya Peraturan Menteri Pertanian No.67/Permentan/OT.140/5/2014 tentang persaratan mutu dan Pemasaran Biji Kakao. 


\subsection{Arah Pengembangan Kakao Di Provinsi Jambi}

\subsubsection{Penguatan Kelembagaan}

Permasalahan utama perkebunan kakao di Provinsi Jambi sebagian besar masih bertumpu pada petani yaitu rendahnya produktivitas dan mutu produk kakao serta permasalahan harga yang diterima petani tidak berbeda antara biji kakao fermentasi dan non-fermentasi. Permasalahanpermasalahan tersebut seharusnya tidak dihadapi sendiri oleh petani tetapi perlu dukungan kerjasama dari pihak-pihak atau lembaga lain dalam lingkup perkebunan kakao.

Petani berperan sebagai pemilik perkebunan kakao menghasilkan buah kakao dan mendapat pembayaran langsung (tunai) pada saat menjual hasil panennya berupa biji kakao kering (non fermentasi). Kegiatan usaha tani hingga pascapanen yang dilakukan petani memerlukan waktu panjang dan dilakukan sendiri oleh keluarga inti petani yang terdiri atas ayah, ibu dan terkadang pada saat panen dibantu oleh saudara dekat dari keluarga inti. Keterbatasan tenaga dan waktu mengakibatkan petani keberatan melakukan proses pengolahan biji kakao fermentasi yang memerlukan tambahan waktu 4-5 hari, apalagi harga yang diterima dari penjualan biji fermentasi dan non fermentasi tidak berbeda jauh.

Kegiatan usaha tani kakao oleh petani meliputi pemangkasan, pembuangan tunas air, pemupukan, pengendalian gulma, pengendalian hama dan penyakit dan pemanenan. Untuk kegiatan pascapanen, petani memerlukan waktu 1-2 hari untuk membelah buah dan mengeluarkan bijinya. Pemanenan oleh sebagian besar petani masih dilakukan dengan cara manual yaitu menggunakan parang untuk membelah buah kakao. Selanjutnya biji kakao basah diperam dalam karung selama 1-2 malam dan dilanjutkan dengan pengeringan biji pada lantailantai jemur di pekarangan rumah. Tidak jarang sebelum biji kakao mencapai kadar air yang dipersyaratkan, petani telah menjual hasil panen pada pedagang-pedagang pengumpul. Keputusan petani ini mengakibatkan rendahnya pendapatan yang diterima oleh petani.

Oleh karena itu, dengan pertimbangan efisiensi dan skala usaha seharusnya proses pascapanen biji kakao dilakukan di tingkat kelompok tani. Kelompok tani membentuk sub-sub kelompok yang terdiri atas penanganan pascapanen, sarana prasarana, pengawasan mutu dan pembelian dan pemasaran. Kegiatan terintegrasi yang dilengkapi sarana dan prasarana untuk melakukan kegiatan penanganan pascapenen, sampai dengan pemasaran biji kakao yang dilakukan dalam satu atap manajemen. Kelompok tani ini harus menjalin kerjasama dengan petani, sehingga petani merupakan asset yang sangat berharga karena untuk menjamin ketersediaan bahan baku (biji kakao basah).

Perlengkapan yang harus dimiliki pada kelompok tani seperti peralatan mesin pemecah buah, unit fermentasi, ruang pengering, mesin sortasi, ruang pengering dan peralatan lainnya berada di kelompok petani. Kelompok tani menghasilkan biji kakao kering fermentasi yang sesuai standar mutu untuk kebutuhan industri sesuai dengan persyaratan mutu SNI. Sebenarnya proses fermentasi dapat meningkatkan harga jual biji kakao dan dapat berdampak pada peningkatan pendapatan petani secara keseluruhan. Secara umum harga kakao biji non fermentasi di tingkat petani beberapa tahun terakhir berkisar antara Rp 20.000-Rp 25.000/kg/biji kering, sedangkan untuk kakao biji kakao fermentasi berkisar antara Rp 30.000-Rp $35.000 / \mathrm{kg} / \mathrm{biji}$ kering.

Kelompok-kelompok tani yang berada di satu desa harus membentuk gabungan kelompok tani (gapoktan) yang dapat ditransformasikan menjadi koperasi petani (Listyati at al.2014). Gapoktan/koperasi tersebut berperan sebagai 1) penyedia sarana produksi usahatani kakao bagi petani/kelompok tani (pupuk, pestisida, benih), 2) koperasi simpan pinjam, 3) penyalur biji kakao dari tingkat kelompok petani, 4) penyedia dana talangan untuk produksi bij kakao yang dihasilkan oleh petani/kelompok tani (Listyati et al. 2014). Tidak semua kelompok tani memiliki sarana transportasi untuk menjual hasil panen langsung ke pedagang besar. Peran pedagang pengumpul untuk mendatangi kelompok tani yang telah siap menjual biji. 


\section{PENUTUP}

Pada era globalisasi ini pelaksanaan pembangunan perkebnan harus memperhatikan kelestarian ekosistem dan memberdayakan masyarakat sekitar sehingga tidak akan mengakibatkan terjadinya degradasi lahan maupun permasalahan sosial yang lain. Karena pada dasarnya program pembangunan pertanian berkelanjutan (berwasan lingkungan) berawal dari permasalahan pokok tentang bagaimana mengelola sumberdaya lahan secara bijaksana sehingga bisa menopang kehidupan yang berkelanjutan bagi masyarakat dan generasi penerus.

Untuk itu, kelembagaan petani perlu dikuatkan melalui pelatihan dan pendampingan petani serta memperbanyak petugas pendamping di lapangan. Kemitraan usaha antara industri/eksportir dengan petani/kelompok tani perlu ditumbuhkan dan ditingkatkan. Kemitraan usaha yang diharapkan adalah kemitraan yang profesional saling menguntungkan dan tidak terbatas dan hanya pemasaran hasil tetapi termasuk teknis budidaya dan peningkatan mutu. Meningkatkan kualitas ekspor kakao dari kakao biji menjadi kakao bubuk atau produk olahan.

\section{DAFTAR PUSTAKA}

Badan Litbang Pertanian. 2014. Rencana Strategis Badan Penelitian dan Pengembangan Pertanian 2015-2019. Kementerian Pertanian. Badan Litbang Pertanian. Jakarta.

Dewan Kakao Indonesia, menyongsong pemberlakuan peraturan Menteri Pertanian, No.67/Permentan/OT.140/5/2014 tentang Persyaratan Mutu dan Pemasaran Biji Kakao, disampaikan pada Lokakarya, 27-28 Mei 2015, Suraqbaya.

Dinas Perkebunan Provinsi Jambi, 2015. Peluang Investasi Komoditas Utama Perkebunan. Invesment Opportunity of Estate Crops Main Communities.

Dinas Kehutanan dan Perkebunan Kabupaten Muaro Jambi, Manual Perbenihan ， menyongsong Komoditas Kakao, 2011.

Direktoran Jenderal Perkebunan, Petunjuk Teknis Budidaya Kakao Rakyaqt, 2012.

Direktoran Jenderal Perkebunan, Kakao, 1995.

Direktorat Jenderal Perkebunan, Road Map Komoditi Kakao 2005-2025-2006

Pusat Penelitian Kopi dan Kakao Indonesia, Panduan Lengkap Budidaya Kakao, 2004.

Puslitbang Perkebunan. 2016. Program Kegiatan Jangka Menengah 2015-2019. Materi dipaparkan dalam diskusi di Balai Besatr Pengkajian dan Pengembangan Teknologi Pertanian.

Peraturan Menteri Pertanian No.50./Permentan/CT.140/8/2012. Tentang Pedoman.

Pengembangan Kawasan Pertanian. Kementerian Pertanian. Siregar,H.S. Tumpal, Slamet Riyadi, Laeii Nuraeni, Coklat, 1998

Kementerian Pertanian Direktorat Jenderal Perkebunan, Pedoman Teknis Budidaya Kakao Yang Baik, Jakarta 204.

Kementrian Pertanian Direktorat Jenderal Pengolahan dan Pemasaran Hasil Pertanian, Persyaratan Mutu dan Pemasaran Biji Kakao, 2015.

Kementerian Pertanian, Direktorat Jenderal Perkebunan. Buku Profil Kakao, 2015.

Supriyati, Suryani E. 2006. Peranan, Peluang dan Kendala Pengembanga Agroindustri di Indonesia. Jurnal Forum Penelitian Agro Ekonomi. 24 (2) : 92-106.

Zulfiandi, Mirimin. 2012. Strategi Pengembangan Agroindustri Kakao Berbasis Kelompok Tani di Propinsi Sumatera Barat. Jurnal Inovisi. 8(1) : 1-13. 